\title{
Bacillus licheniformis APase I gene promoter: a strong well-regulated promoter in B. subtilis
}

\author{
JungWan K. Lee, Charles W. Edwards and F. Marion Hulett* \\ Laboratory for Molecular Biology, University of Illinois at Chicago, PO Box 4348, Chicago, IL 60680, USA
}

(Received 2 January 1991; revised 21 January 1991; accepted 6 February 1991)

\begin{abstract}
The $5^{\prime}$ regulatory region and the portion of the structural gene coding for the amino-terminal sequence of alkaline phosphatase I (APase I) were isolated from Bacillus licheniformis MC14 using a synthetic oligodeoxynucleotide deduced from the amino acid sequence of the enzyme. The DNA sequence analysis of this region revealed an open reading frame of 129 amino acids containing the amino-terminal sequence of the mature APase protein. The protein sequence was preceded by a putative signal sequence of 32 amino acid residues. The predicted amino acid sequence of the partial APase clone as well as the experimentally determined amino acid sequence of the enzyme indicated that $B$. licheniformis APase retains the important features conserved among other APases of Bacillus subtilis, Escherichia coli, Saccharomyces cerevisiae, and various human tissues. Heterologous expression studies of the promoter using a fusion with the $l a c Z$ gene indicated that it functions as a very strong inducible promoter in $B$. subtilis that is tightly regulated by phosphate concentration.
\end{abstract}

\section{Introduction}

Bacillus licheniformis $\mathrm{MC14}$, a facultatively thermophilic Gram-positive bacterium, was chosen for the study of alkaline phosphatase [orthophosphoric-monoester phosphohydrolase (alkaline optimum), EC 3.1.3.1; APase] based on its capability of hyper-production of APase (Hulett \& Campbell, 1971). In the presence of $\mathrm{Co}^{2+}, B$. licheniformis $\mathrm{MC} 14$ produces 35 times more APase activity than reported for other Bacillus species (Hydrean et al., 1977) and $99 \%$ of the APase synthesized is efficiently secreted into the culture medium (Spencer $e t$ al., 1981).

Biochemical studies of $B$. licheniformis MC14 APase have indicated that there exist multiple APase species in this bacterium whose expression can be derepressed upon phosphate starvation during vegetative growth (McNicholas \& Hulett, 1977; Hansa et al., 1981; Spencer \& Hulett, 1981; Spencer et al., 1982; Hulett et al., 1986). The expression and localization of APase enzymes in the cell are dependent on the age of the culture as well as the

Abbreviations: APase, alkaline phosphatase; PVDF, polyvinylidene difluoride.

The nucleotide sequence data reported in this paper have been submitted to GenBank and have been assigned the accession number M37169. culture conditions. The major APase species in $B$. licheniformis MC14 has a molecular mass of $60 \mathrm{kDa}$ (Hulett \& Campbell, 1971). The amino acid compositions are very similar among the APase species, but not identical. It has been our working hypothesis that there are multiple structural genes responsible for each APase species in B. licheniformis MC14. However, it is not likely that the hyper-production of APase in $B$. licheniformis MC14 compared to other Bacillus species is due solely to the existence of multiple APase genes, since it has been shown recently that there are multiple APase genes in $B$. subtilis (Hulett et al., 1990). B. subtilis produces (or secretes) only one-sixteenth of the total APase activity produced by $B$. licheniformis $\mathrm{MC} 14$ under similar culture conditions (Hulett \& Jensen, 1988). Therefore, the nature of the hyper-production of APase in B. licheniformis $\mathrm{MC1} 4$ is more likely to be the result of a difference in the promoter strength of one or more of the APase structural genes.

Efforts to isolate APase structural genes from Bacillus by complementation of an Escherichia coli phoA strain have not been successful (Hulett et al., 1988; Lee et al., 1991). Previous problems in sequencing the APase protein were overcome by employing a new technique using the PVDF (polyvinylidene difluoride) immobilon (Matsudaira, 1987). In this paper, we report the cloning of the amino terminus of the APase structural gene from $B$. licheniformis MC14 using the protein sequence data. 
The possible usage of the promoter of the APase gene is also discussed based on the results of the expression study of the promoter.

\section{Methods}

Bacterial strains and plasmids. B. licheniformis MC14 was used to isolate APase protein (Hulett \& Campbell, 1971). B. subtilis IS401 ( $\operatorname{trpC2}$ pheAl) (from I. Smith) was the wild-type strain used for the expression study. E. coli $\mathrm{DH} 5 \alpha\left[\mathrm{F}^{-} \phi 80 \mathrm{~d} l a c Z \Delta \mathrm{M} 15 \Delta\left(\right.\right.$ lac $Z Y A^{-}$ argF)U 169 recAl end Al hsdRI7 $\left(\mathrm{r}_{\mathrm{k}}^{-} \mathrm{m}_{\mathrm{k}}^{+}\right)$supE44 $\lambda^{-}$thi- 1 gyrA relAl] was used as a recipient for cloning and culturing recombinant plasmids. The E. coli vector, pJM103, was generated by ligating pUC 19 and the Gram-positive chloramphenicol resistance gene, and was used in cloning the APase gene (Ferrari \& Hoch, 1989). The integration expression vector, $\mathrm{pDH} 32$, contained an $a m y E$ gene interrupted by a promoterless $l a c Z$ gene fused to the ribosome-binding site of the $s p o V G$ gene and the Gram-positive chloramphenicol resistance gene (Shimotsu \& Henner, 1986). It also carried a penicillin resistance gene and an origin for replication in $E$. coli.

Purification of membrane-associated APase. APase enzyme was purified from B. licheniformis $\mathrm{MCl} 4$ as described by Hulett et al. (1976).

Amino acid sequencing. APase for sequencing was run on a $7.5 \%(w / v)$ SDS-PAGE gel and blotted onto PVDF immobilon as described by Hulett et al. (1990). The $60 \mathrm{kDa}$ protein band containing APase protein was cut out after staining and destaining of the membrane and analysed by the Harvard Microchemistry facility on a $470 \mathrm{~A}$ protein sequencer equipped with a $120 \mathrm{~A}$ on-line PTH-AA analyser (Applied Biosystems).

Oligodeoxynucleotide synthesis. Oligodeoxynucleotides were synthesized on a Biosearch 8700 DNA synthesizer and cartridge purified. The oligodeoxynucleotides synthesized for plasmid sequencing were 15 nucleotides long and based on previous sequencing data. The oligodeoxynucleotide synthesized for DNA hybridization, SOKL56, was 56 nucleotides long and deduced from the amino acid sequencing data. Where codons were redundant, the one most likely to be used by Bacillus (Piggot \& Hoch, 1985) was chosen to be included in the sequence.

Recombinant DNA techniques. Restriction enzymes and T4 DNA ligase were purchased from Bethesda Research Laboratories (BRL) and used according to the manufacturer's recommendations. Plasmid DNA was isolated from E. coli according to Maniatis et al. (1982). Bacillus chromosomal DNA was isolated as described by Bookstein $e t$ al. (1990).

Southern hybridization. Southern hybridizations were carried out on Hybond- $\mathrm{N}$ nylon membranes according to Amersham membrane transfer detection methods. The probes were prepared either by labelling plasmids with $[\alpha-32 \mathrm{P}] \mathrm{CTP}$ using the nick-translation kit from BRL or by end-labelling the oligodeoxynucleotide, SOKL56, with T4 polynucleotide kinase from BRL. To end-label the synthetic oligodeoxynucleotide, $100 \mathrm{pmol}$ SOKL56 was incubated with $100-150 \mathrm{pmol}[\gamma-$ ${ }^{32}$ P]ATP [specific activity $>4500 \mathrm{Ci} \mathrm{mmol}^{-1}\left(>166.5 \mathrm{TBq} \mathrm{mmol}^{-1}\right)$, Amersham, or $\left.>7000 \mathrm{Ci} \mathrm{mmol}^{-1}\left(>259 \mathrm{TBq} \mathrm{mmol}^{-1}\right), \mathrm{ICN}\right]$ and T4 polynucleotide kinase at $37^{\circ} \mathrm{C}$ for $30 \mathrm{~min}$ (Maniatis et al., 1982). Conditions of stringency for hybridization and wash were determined as described by Bookstein et al. (1990). According to that method, $59^{\circ} \mathrm{C}$ represented $100 \%$ stringency and $47^{\circ} \mathrm{C}$ represented $90 \%$ stringency.

Construction and screening of the sub-genomic DNA libraries. In order to construct sub-genomic DNA libraries, B. licheniformis $\mathrm{MC14}$ chromosomal DNA was digested by the restriction enzyme of interest and separated on an agarose gel by electrophoresis. To increase the possibility of cloning the right fragment, DNA fragments of an appropriate size range as determined by Southern analysis were eluted electrophoretically onto a strip of DEAE cellulose membrane (Schleicher \& Schuell, NA-45) according to the manufacturer's instructions. The DNA fragments were then ligated to an $E$. coli vector, pJM103, after elution from the DEAE membrane. Each sub-genomic DNA library was transformed into a recA E. coli strain, DH5 $\alpha$, and spread directly onto Amersham nylon membranes. Preparation of filters with fixed colonies and colony blot hybridization of the filters were done essentially as described by Lampe et al. (1988) with the modifications made by Bookstein et al. (1990). Usually, 2000-3000 colonies were screened for each sub-genomic library, using $10^{7}$ c.p.m. of the ${ }^{32} \mathbf{P}$ end-labelled SOKL56 as a probe.

Transformation. Transformations of E. coli DH5 $\alpha$ with sub-genomic DNA libraries were carried out by the method of Hanahan (1985). Transformation of $B$. subtilis was carried out by a modification of the method of Dubnau et al. (1969).

DNA sequencing. The nucleotide sequence of the amino-terminal region of the APase I gene and its 5 -flanking region was determined by plasmid sequencing using Sequenase kits purchased from United States Biochemical and following the manufacturer's instructions. Both strands of DNA sequence were determined using universal primers and oligonucleotides synthesized based on previous sequencing data.

APase assay. APase assays of $B$. subtilis strains were performed on culture supernatants from cells grown in defined medium as described previously (Spencer et al., 1981; Hulett \& Jensen, 1988). Units of activity were calculated as $\mu \mathrm{mol} p$-nitrophenol phosphate hydrolysed $\min ^{-1}$ at $\mathrm{pH} 9.5$ in $1 \mathrm{M}$-CHES buffer (Sigma) with $0.1 \mathrm{mM}^{-\mathrm{CoCl}_{2}}$, $70 \mathrm{~mm}-\mathrm{MgSO}_{4}$ and $10^{-5} \mathrm{~mm}-\mathrm{ZnCl}_{2}$. Specific activity was calculated as units of activity per ml culture divided by $\mathrm{OD}_{525}$.

$\beta$-Galactosidase assay. The $\beta$-galactosidase plate assay was done using defined medium agar plates supplemented with $50 \mu \mathrm{g}$ 5-bromo-4chloro-3-indolyl $\beta$-D-galactosidase (X-Gal) $\mathrm{ml}^{-1}$, containing either low phosphate $(0.4 \mathrm{~mm})$ or high phosphate $(45 \mathrm{~mm}) . \beta$-Galactosidase assay was also done on cultures grown in defined medium containing either low phosphate $(0.4 \mathrm{~mm})$ or high phosphate $(10 \mathrm{~mm})$ as described by Ferrari et al. (1986). $\beta$-Galactosidase specific activity was expressed in units $(\mathrm{mg} \text { protein })^{-1}$. The unit used was equivalent to $0.33 \mathrm{nmol}$ orthonitrophenol produced $\mathrm{min}^{-1}$.

\section{Results and Discussion}

Amino acid sequencing of B. licheniformis MC14 APase I

Previous attempts to sequence the amino terminus of $B$. licheniformis MC14 APase protein yielded results suggesting that the amino terminus may be blocked for protein sequencing. However, the new protein blotting technique using an immobilon (Matsudaira, 1987) made it possible to determine the amino acid sequence of the enzyme in the amino-terminal region. The $60 \mathrm{kDa}$ membrane-associated APase was purified from $B$. licheniformis $\mathrm{MC14}$ by $\mathrm{Mg}^{2+}$ extraction (Hulett et al., 1976; Spencer \& Hulett, 1981 ; Spencer et al., 1982) and its first 21 amino acid residues at the amino terminus were determined. The sequence (Fig. 2, underlined) showed homology to the sequence of the first $\beta$-sheet strand, strand $\mathrm{A}$, and the aspartic acid residue providing 


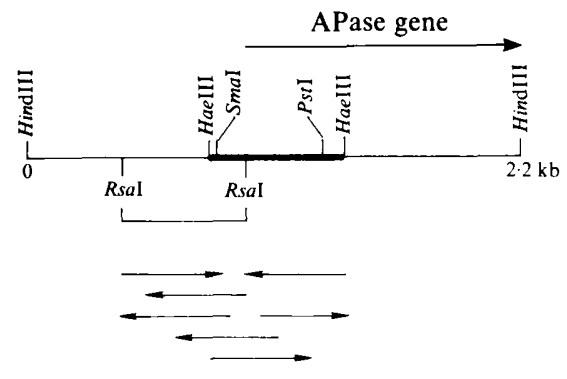

Fig. 1. Restriction map of the $2.2 \mathrm{~kb}$ HindIII fragment and DNA sequencing strategy. The arrow above the map indicates the direction of the APase I gene. The 593 bp HaeIII fragment which was isolated separately is shown by a thick line. The $625 \mathrm{bp} \mathrm{RsaI}$ fragment used for the expression study of the promoter is indicated by a line binding the two sites. The nucleotide sequence of the $1020 \mathrm{bp} \mathrm{Rsal-HaeIII}$ fragment was determined by plasmid sequencing using universal primers or the synthetic oligonucleotides.

a ligand to the metal-binding site B of $E$. coli APase (Wyckoff et al., 1983). These domains are known to be conserved among APases from various organisms including two B. subtilis APases (Kim \& Wyckoff, 1989; Hulett et al., 1990). A 56-nucleotide oligodeoxynucleotide was synthesized based on the amino acid sequence data, using the codon with the highest usage in Bacillus for each amino acid (Piggot \& Hoch, 1985). The following is the sequence of the synthetic oligodeoxynucleotide, SOKL56: 5'-AAA-AAA-AAA-GAA-GAACCG-AAA-GTT-AAA-AAT-GTT-ATT-ATG-ATGGTT-ATG-GAG-GAA-AC-3'.

\section{Southern analysis of $B$. licheniformis MC14 genomic DNA}

To determine the sizes of $B$. licheniformis MC14 chromosomal DNA fragments containing the amino terminus of the APase structural gene, the chromosomal DNA was digested with various restriction enzymes and probed with the synthetic oligodeoxynucleotide SOKL56. B. licheniformis MC14 chromosomal DNA digested with Pstl, HindIII, PtuII, HaeIII or Rsal showed a $4.5 \mathrm{~kb}$, a $2.2 \mathrm{~kb}$, a $3.5 \mathrm{~kb}$, a 593 bp or a $625 \mathrm{bp}$ fragment, respectively, when probed with end-labelled SOKL56 at a stringency of $90 \%$ (data not shown). $B$. subtilis chromosomal DNA digests showed three PstI DNA fragments $(2.8 \mathrm{~kb}, 4.4 \mathrm{~kb}$ and $6.0 \mathrm{~kb})$ hybridizing to SOKL56 at a stringency lower than $80 \%$, but none was detected at higher stringency (data not shown). The $2.8 \mathrm{~kb}$ and the $4.4 \mathrm{~kb}$ fragments were the sizes of the $P s t \mathrm{I}$ DNA fragments containing the APase III and APase IV genes of B. subtilis (Hulett et al., 1990, and unpublished data). This suggested that APase genes in these two Bacillus species were similar to each other at the DNA sequence level. Bacillus APases are immunologically related to each other, but not to E. coli APase (Hulett et al., 1990).

\section{Cloning the $5^{\prime}$ regulatory and structural terminus of the APase I gene of $B$. licheniformis}

To avoid problems associated with DNA rearrangements which we experienced in cloning the complete $B$. subtilis APase structural genes in E. coli, a sub-genomic DNA library was constructed in an $E$. coli vector, pJM103, using the HaelII fragments of $B$. licheniformis MCl4 genomic DNA in the range $0.5-1 \mathrm{~kb}$. Two thousand colonies were screened by colony hybridization using the end-labelled SOKL56, and three of them with strong signals were found to contain the same $593 \mathrm{bp}$ HaeIII DNA fragment. The Southern analysis of $B$. licheniformis $\mathrm{MCl} 4$ genomic DNA digests using the Haell clone as the probe ensured the cloning of the correct DNA fragment, later confirmed by DNA sequencing analysis (see below). The $2.2 \mathrm{~kb}$ HindIII fragment was also cloned in a similar way by screening the HindIII sub-genomic library with SOKL56. The restriction mapping of these clones indicated that the $593 \mathrm{bp}$ HaellI fragment was internal to the $2.2 \mathrm{~kb}$ HindIII fragment as shown in Fig. 1. The HindIII clone provided 5' APase I flanking DNA required for assessing the promoter function of this gene.

Sequencing analysis of the $593 \mathrm{bp} \mathrm{HaeIII}$ fragment and flanking 5'DNA

The nucleotide sequence of the $593 \mathrm{bp} \mathrm{HaeIII} \mathrm{fragment}$ region was determined to ensure that we had cloned the portion of the gene encoding the amino-terminal region of the APase I protein of B. licheniformis MC14. The sequence of its $5^{\prime}$ flanking DNA which was used for promoter expression study was also determined (see below). The sequencing strategy is shown in Fig. 1 and the sequence is shown in Fig. 2. The nucleotide sequence of the $593 \mathrm{bp} \mathrm{HaeIII}$ fragment showed an open reading frame of 129 amino acids containing a predicted amino acid sequence identical to the amino acid sequence determined experimentally (Fig. 2, underlined). The amino-terminal sequence of the mature APase was preceded by a putative signal sequence of 32 amino acid residues. The putative signal sequence contained two positively charged arginine residues, at positions -26 and -28 , and a stretch of 25 hydrophobic amino acid residues. The putative cleavage site had an alanine, which is a typical residue found at the cleavage site in Gram-positive bacterial signal sequences (von Heijne \& Abrahmsen, 1989). The probable translation initiation 


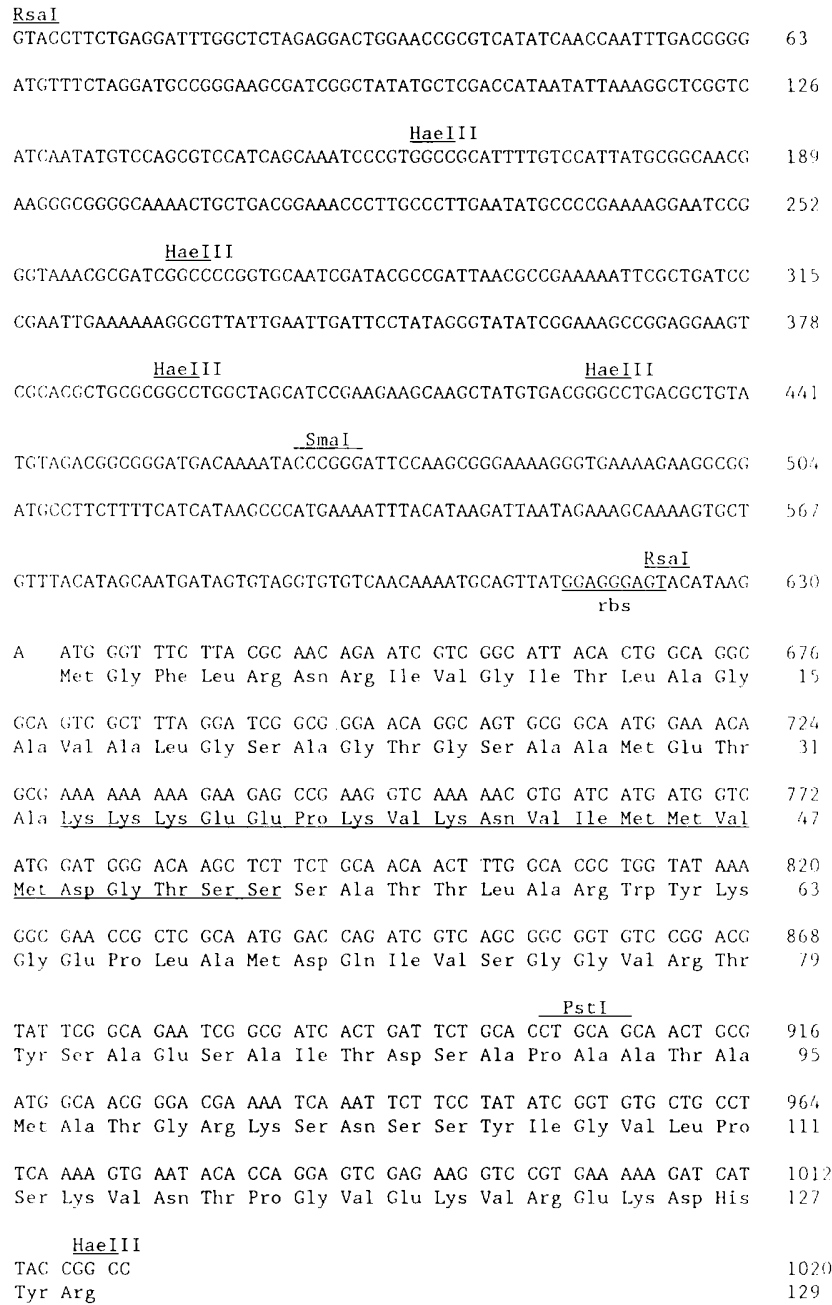

Fig. 2. Nucleotide sequence of the 593 bp HaeIII fragment and its $5^{\prime}$ flanking DNA. The sequence contained the amino-terminal portion of the APase I gene and the promoter region that was used for the expression study. Numbering begins at the $5^{\prime}$ end of the sequence. The predicted amino acid sequence of the APase I gene is shown below the DNA sequence in three-letter code, beginning at 632. The putative ribosome-binding site is underlined and marked as rbs. The predicted amino acid sequence that is identical to the amino acid sequence determined experimentally is underlined and preceded by an alanine, which is the typical residue found at the cleavage site of a signal sequence.

site was a methionine, ATG, at position 632 , which was preceded by a potential ribosome-binding site, GGAGGGAGT, 8 bp upstream. The predicted amino acid sequence of the mature APase showed homology to the amino-terminal sequences of APases from other organisms including E. coli (Chang et al., 1986), B. subtilis (Hulett et al., 1991), Saccharomyces cerevisiae (Kaneco et al., 1987), and human (Kam et al., 1985; Weiss et al., 1988) (Fig. 3). The amino acid sequence of $B$. licheniformis APase, in this region, showed approximately $24-29 \%$ identity with the amino acid sequence of

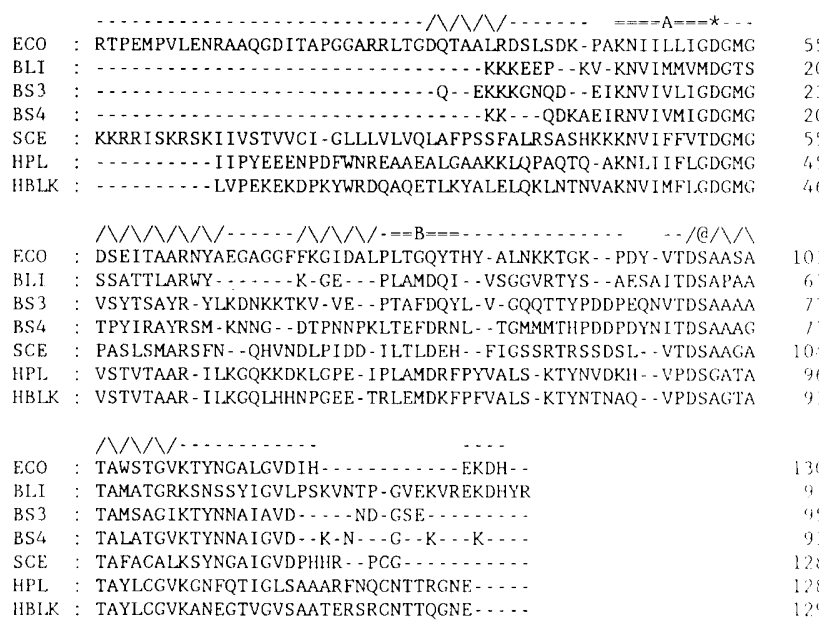

Fig. 3. Comparison of the amino-terminal amino acid sequence of APase I with other APases. The sequence of the first 97 amino acid residues of the mature $B$. licheniformis APase I protein (BLI) is highly homologous to conserved regions of E. coli (ECO), B. subtilis (BS3 and BS4), $S$. cerecisiae (SCE), human placenta (HPA), and human boneliver-kidney (HBLK) APases. The,$===,^{*}$, and ( $a$ marks represent the $\alpha$-helix, $\beta$-sheet, a ligand to metal-binding site $B$, and phosphorylation site, respectively, as determined by the analysis of crystallized E. coli APase (Wyckoff et al., 1983; Hulett et al., 1991).

each of the above APases, being most closely similar to B. subtilis APases. Some structurally and functionally important features as determined from X-ray diffraction study of the crystallized $E$. coli APase are conserved in this region (Kim \& Wyckoff, 1989). The first two $\beta$-sheet strands, A and B, are conserved among APases. The aspartic acid providing one of the ligands to the metalbinding site $\mathrm{B}$ and the serine residue at the phosphorylation site are conserved in all APases. It is interesting that, like other Bacillus APases, B. licheniformis APase is also truncated such that the first $\beta$-sheet strand is very close to the amino-terminus (Hulett et al., 1990). The results of the DNA sequencing and comparison analysis of the predicted amino acid sequence indicated that we had cloned the DNA fragment for the amino-terminal portion of the APase structural gene (APase I gene) from $B$. licheniformis $\mathrm{MC} 14$ and its $5^{\prime}$ flanking region.

\section{Expression study using the promoter for the APase I gene in B. subtilis}

The expression and the strength of the promoter for the APase I gene of $B$. licheniformis MC14 were studied in $B$. subtilis IS401. For this purpose the $625 \mathrm{bp} R$ saI fragment (Fig. 1) was cloned in an integration vector $\mathrm{pDH} 32$ (Shimotsu \& Henner, 1986; Fig. 4) in an orientation which resulted in the construction of a transcriptional fusion between the APase I gene promoter and the promoterless lac $Z$ structural gene. The $625 \mathrm{bp} R s a \mathrm{I}$ 


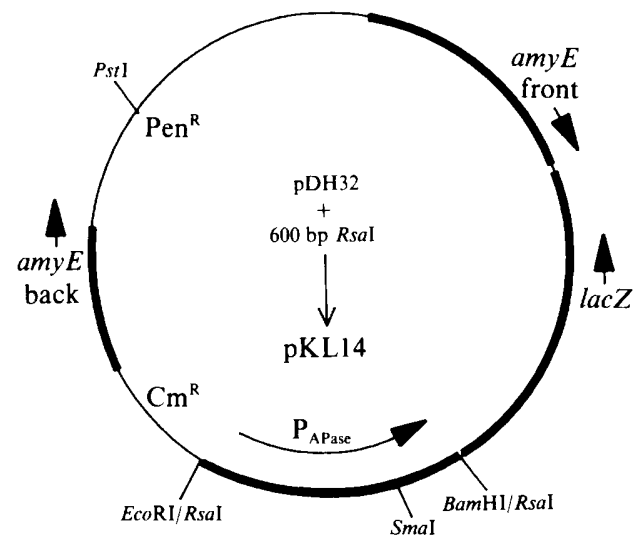

Fig. 4. Map of the expression clone, pKL14. The 625 bp RsaI fragment was ligated to the $S m a I$ site of pJM103 first, and then cloned between the EcoRI and BamHI sites of pDH32 $(9.8 \mathrm{~kb})$ using the EcoRI and $B a m \mathrm{HI}$ sites in the polylinker of pJM103. The arrow indicates the direction of transcription of each gene or the promoter. The lac $Z$ gene lacks its own promoter and is fused to the ribosome-binding site of the spoVG gene. The penicillin resistance gene $\left(\mathrm{Pen}^{\mathrm{R}}\right)$ was derived from pBR322 and the chloramphenicol resistance gene $\left(\mathrm{Cm}^{\mathrm{R}}\right)$ from pC194.

fragment which contains the putative ribosome-binding site and further upstream sequence (Fig. 1) was first ligated to the SmaI site of pJM103 and then the insert was cloned into pDH32 at the EcoRI and BamHI sites using the EcoRI and BamHI sites in the polylinker of pJM103. The resulting expression clone, pKL14, was linearized at the unique PstI site and used to transform competent cells of $B$. subtilis IS401. The linearized DNA was integrated into the chromosomal DNA by gene replacement at the amyE locus. The construct was selected by chloramphenicol resistance and screened for the loss of $\alpha$-amylase synthesis on starch agar plates. The proper rearrangement in the chromosomal DNA was confirmed by Southern analysis (data not shown). $\mathrm{MH} 1000$ and MH1400 contained the amyE portion of $\mathrm{pDH} 32$ and $\mathrm{pKL} 14$, respectively, at the amyE locus on the chromosome. Assay of MH1400 for $\beta$-galactosidase production on low-phosphate defined agar medium supplemented with X-Gal showed a blue colony phenotype. This promoter activity was not detected on high (45 mM) phosphate defined agar medium. Both MH1000 and the parental strain, IS401, remained white on both types of agar. These data indicated that the RsaI fragment in front of the APase I open reading frame retained phosphate-starvation-inducible ( $\mathrm{psi}$ ) promoter activity in $B$. subtilis.

In order to study the expression pattern of the APase I gene promoter during the course of vegetative growth and to measure the strength of the promoter, $\beta$ galactosidase activity of MH1400 was monitored by liquid culture assay in low-phosphate defined medium
(Fig. 5). In order to avoid the excessive APase and $\beta$ galactosidase activity in the initial inoculum carried over from overnight culture, cells were grown in lowphosphate defined medium to early exponential phase. Cells were collected by centrifugation, suspended in lowphosphate defined medium and used to inoculate fresh defined medium containing either low phosphate $(0.4 \mathrm{mM})$ or high phosphate $(10 \mathrm{~mm})$. The $B$. licheniformis APase I promoter initiated expression of $\beta$-galactosidase activity $1 \mathrm{~h}$ later than the derepression of $B$. subtilis vegetative APase after $3 \mathrm{~h}$ growth, as the culture $\mathrm{OD}_{525}$ exceeded 1.0 (Fig. $5 a, b$ ). $\beta$-Galactosidase specific activity increased from $<10$ to 7800 between $3 \mathrm{~h}$ and $5 \mathrm{~h}$ (Fig. $5 a$ ). The specific activity of $\beta$-galactosidase directed by the APase promoter reached a maximum of 7900 after $8 \mathrm{~h}$ growth, indicating that it may be at least more than five times stronger than the APase III promoter of B. subtilis (C. Bookstein and others, unpublished data). The $B$. licheniformis APase I gene promoter was completely repressed by phosphate in the growth medium until $3 \mathrm{~h}$ (Fig. $5 c$ ). The repression factor was greater than $10^{3}$ when fully induced $\beta$-galactosidase activity (Fig. $5 a, 6 \mathrm{~h}$ ) was compared to that of phosphaterepressed APase I promoter at the same hour of growth (Fig. $5 c, 6 \mathrm{~h}$ ). This result agreed with the result of a separate phosphate repression experiment in which the culture grown in low-phosphate defined medium was split into two flasks when the cells reached the end of exponential growth; excess phosphate $(10 \mathrm{~mm})$ was added to one of the flasks. The culture which received additional phosphate resumed exponential growth and ceased to produce APase and $\beta$-galactosidase immediately (data not shown). The culture which received no additional phosphate entered stationary phase and continued to express APase and $\beta$-galactosidase activities similar to those of the culture in Fig. $5(a)$. The $\beta$ galactosidase activity in $\mathrm{MH} 1000$, the strain containing the vector with a promoterless lac $Z$ gene, remained near zero throughout the vegetative growth of the cells in defined medium containing either high or low phosphate (Fig. $5 b, d$ ). The medium (DM) used in these studies is a complete medium in which growth of $B$. subtilis ceases because of limiting phosphate (Hulett \& Jensen, 1988). Induction of the APase I promoter was dependent on the phosphate concentration and was initiated during exponential growth between 3 and $4 \mathrm{~h}$, when the phosphate concentration was $0 \cdot 1-0.08 \mathrm{~mm}$. Altering growth conditions to slow the growth rate increased the length of time between induction of the APase I promoter and the beginning of stationary phase. The timing of APase induction and the beginning of stationary phase remained dependent on the phosphate concentration, but the concentrations required for initiation of each of the two events were different. Forms 


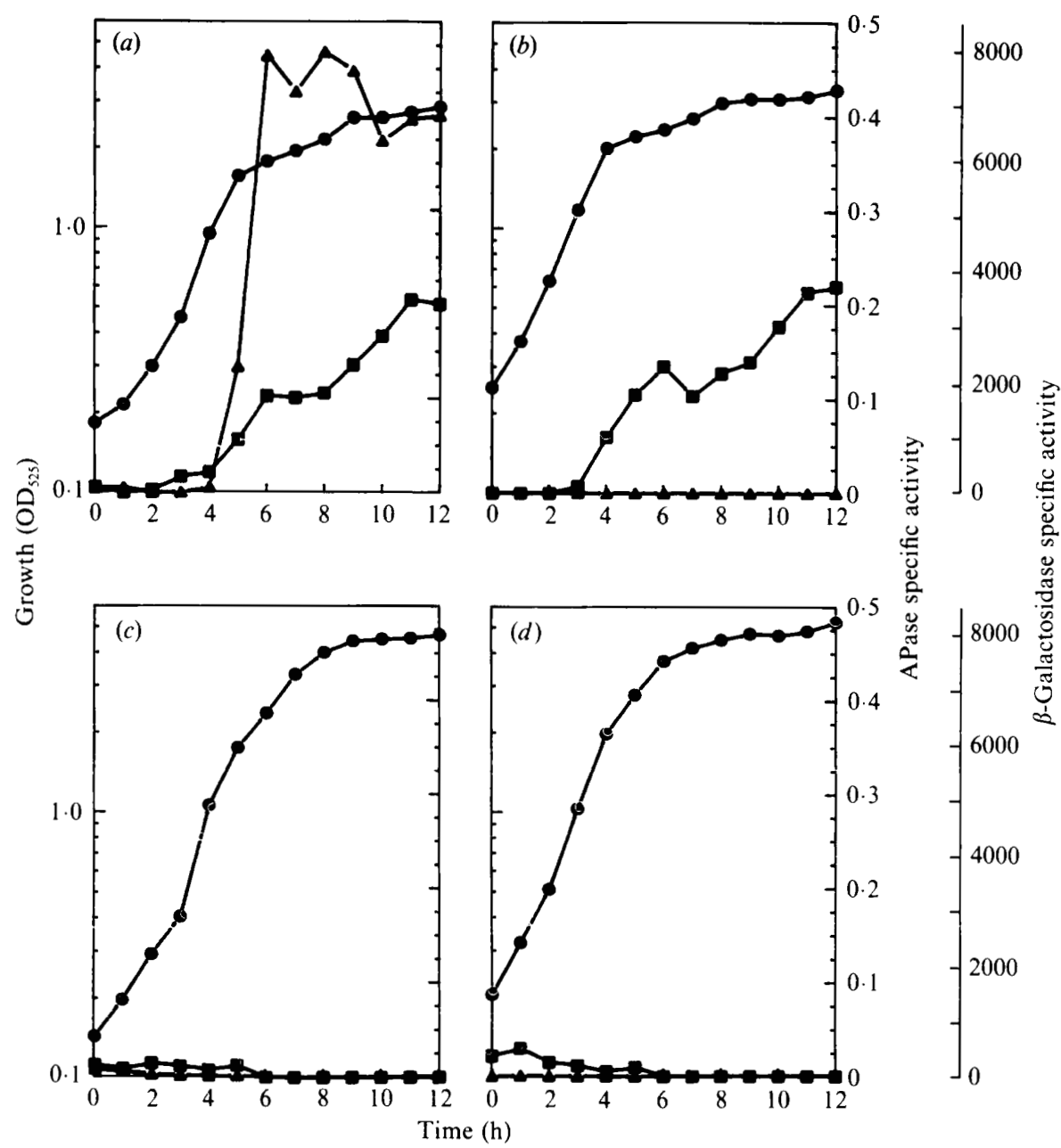

Fig. 5. Expression of the APase I gene promoter in B. subtilis. Cells carrying the pKL14 fusion (MH1400;a) or pDH32 (MH1000;b) were grown in the low-phosphate defined medium that maximized derepression of vegetative APases. To check the effect of a high concentration of phosphate on the promoter activity, cells were grown in the high-phosphate defined medium containing $10 \mathrm{~mm}$ $\mathrm{K}_{2} \mathrm{HPO}_{4}(\mathrm{MH1} 400, c ; \mathrm{MH1000}, d)$. O. Growth;, specific APase activity; $\boldsymbol{\Delta}$, specific $\beta$-galactosidase activity. Specific activities are expressed as described in Methods.

of regulation other than phosphate depletion that may be involved in the expression of vegetative APase have not yet been determined for either $B$. subtilis or $B$. licheniformis.

The data presented in this communication indicate that the promoter of the $B$. licheniformis APase I gene functions in $B$. subtilis as a very strong promoter regulated by the phosphate concentration of the medium. Therefore, this promoter has potential for use as a powerful tool in constructing expression and secretion vectors for $B$. subtilis, especially when the overexpression of a gene product is detrimental to the host cells.

We thank Dr Ruth S. Chesnut for critical reading of this manuscript and helpful discussion. This work was supported by Public Health Service grant GM 33471 from the National Institutes of Health.

\section{References}

Bookstein, C., Edwards, C. W., Kapp, N. \& Hulett, F. M. (1990). The Bacillus subtilis 168 alkaline phosphatase III gene: the impact of a phoA mutation on total alkaline phosphatase synthesis. Journal of Bacteriology 172, 3730-3737.

Chang, C. N., KuANG, W. \& Chen, E. Y. (1986). Nucleotide sequence of the alkaline phosphatase gene of Escherichia coli. Gene 44, 12I125.

Dubnau, D., Davidoff-Abelson, R. \& Smith, I. (1969). Transformation and transduction in Bacillus subtilis: evidence for separate modes of recombinant formation. Journal of Molecular Biology 45, 155-179.

FERrari, E. \& Hoch, J. A. (1989). Genetics. In Bacillus, pp. 57-72. Edited by C. R. Howard. New York: Plenum.

Ferrari, E., Howard, S. \& Hoch, J. A. (1986). Effect of stage 0 sporulation mutations on subtilisin expression. Journal of Bacteriology 166, 173-179.

Hanahan, D. (1985). Techniques for transformation of E. coli. In DNA Cloning II. A Practical Approach, pp. 109-135. Edited by D. M. Glover. Washington, DC: IRL Press. 
Hansa, J. G., Laporta, M., Kuna, M. A., Reimschuessel, R. \& Hulett, F. M. (1981). A soluble alkaline phosphatase from Bacillus licheniformis MC14: histochemical localization, purification and characterization and comparison with the membrane-associated alkaline phosphatase. Biochimica et Biophysica Acta 675, 390 401.

voN HEIJNE, G. \& ABRAHMSEN, L. (1989). Species-specific variation in signal peptide design: implications for protein secretion in foreign hosts. FEBS Letters 244, 439-446.

Hulett, F. M. \& Campbell, L. L. (1971). Purification and properties of an alkaline phosphatase of Bacillus licheniformis. Biochemistry 10, 1364-1370.

Hulett, F. M. \& Jensen, K. (1988). Critical roles of $s p o 0 A$ and $s p o() H$ in vegetative alkaline phosphatase production in Bacillus subtilis. Journal of Bacteriology 170, 3765 -3768.

HuletT, F. M., SChaffel, S. D. \& Campbell, L. L. (1976). Subunits of alkaline phosphatase of Bacillus licheniformis: chemical, physicochemical, and dissociation studies. Journal of Bacteriology 128, 651-657.

hulett, F. M., Stuckmann, K., Spencer, D. B. \& Sanopollou, T. (1986). Purification and characterization of the secreted alkaline phosphatase of Bacillus licheniformis $\mathrm{MCl}$ 4: identification of a possible precursor. Journal of General Microbiology 132, 2387-2395.

Hulett, F. M., Jensen, K., Bookstein, C., Owen, D., Edwards, C. \& KAPP, N. (1988). In vitro derived phosphatase mutants of Bacillus. In Genetics and Biotechnology of Bacilli, vol. 2, pp. 325-329. Edited by A. T. Ganesan \& J. Hoch. New York: Academic Press.

Hulett, F. M., Bookstein, C. \& Jensen, K. (1990). Evidence for two structural genes for alkaline phosphatase in Bacillus subtilis. Journal of Bacteriolog. 172, $735-740$.

Hulett, F. M., Kim, E. E., Bookstein, C., Kapp, N. V., Edwards, C. W. \& WyCKOFF, H. W. (1991). Bacillus subtilis alkaline phosphatases IIl and IV: cloning, sequencing and comparisons of deduced amino acid sequence with Escherichia coli alkaline phosphatase 3-D structure. Journal of Biological Chemistry 266, 10771084.

Hydrean, C., Ghosh, A., Nallin, M. \& Ghosh, B. K. (1977). Interrelationship of carbohydrate metabolism and alkaline phosphatase synthesis in Bacillus licheniformis 759/C. Journal of Biological Chemistry 252, 6806-6812.

Kam, W., Clauser, E., Kim, Y. S., Kan, Y. W. \& Rutter, W. (1985). Cloning, sequencing, and chromosomal localization of human term placental alkaline phosphatase cDNA. Proceedings of the National Academy of Sciences of the United States of America 82, 8715-8719.

Kaneko, Y., Hayashi, N., Toh-E, A., Banno, I. \& Ohima, Y. (1987). Structural characteristics of the PHO\& gene encoding repressible alkaline phosphatase in Saccharomyces cerevisiae. Gene 58, 137-148.

Kiм, E. E. \& Wyckoff, H. W. (1989). Structure of alkaline phosphatases. Clinica Chimica Acta 186, 175-188.

LAMPE, M., Binnie, C., SChMidT, R. \& Losick, R. (1988). Cloned gene encoding the delta subunit of Bacillus subtilis RNA polymerase. Gene 67, 13-19.

LATHE, R. (1985). Synthetic oligonucleotide probes deduced from amino acid sequence data: theoretical and practical considerations. Journal of Molecular Biology 183, 1-12.

LEE, J. K., EDWARDS, C. W. \& HulETt, F. M. (1991). Identification of four unique clones encoding $10 \mathrm{kDa}$ proteins from Bacillus that cause phenotypic complementation of a phoA mutant strain of Escherichia coli. Journal of General Microbiology 137, 667-677.

Maniatis, T., Fritsch, E. F. \& Sambrook, J. (1982). Molecular Cloning. A Laboratory Manual. Cold Spring Harbor, NY: Cold Spring Harbor Laboratory.

MatsudaiRA, P. (1987). Sequence from picomole quantities of proteins electroblotted onto polyvinylidene difluoride membranes. Journal of Biological Chemistry 262, 10035-10038.

MCNicholas, J. M. \& Hulett, F. M. (1977). Electron microscope histochemical localization of alkaline phosphatase(s) in Bacillus licheniformis. Journal of Bacteriology 129, 501-515.

MeInkoth, J. \& WaHL, G. (1984). Hybridization of nucleic acids immobilized on solid supports. Analytical Biochemistry 138, 267-284.

PigGot, P. \& Hoch, J. A. (1985). Revised genetic linkage map of Bacillus subtilis. Microbiological Reviews 49, 158-179.

Shimotsu, H. \& HenNer, D. J. (1986). Construction of a single-copy integration vector and its use in analysis of regulation of the trp operon of Bacillus subtilis. Gene 43, 85-94.

SPENCER, D. B. \& Hulett, F. M. (1981). Lactoperoxidase-125I localization of salt-extractable alkaline phosphatase on the cytoplasmic membrane of Bacillus licheniformis. Journal of Bacteriology 145 , 934-945.

SPencer, D. B., Chen, C.-P. \& Hulett, F. M. (1981). Effect of cobalt on synthesis and activation of Bacillus licheniformis phosphatase. Journal of Bacteriology 145, 926-933.

Spencer, D. B., Hansa, J., Stuckmann, K. \& Hulett, F. M. (1982). A membrane associated alkaline phosphatase from Bacillus licheniformis $\mathrm{MC} 14$ requiring detergent for solubilization: lactoperoxidase ${ }_{125}$ I and molecular weight determination. Journal of Bacteriology 150, $826-834$.

TaKami, N., Ogata, S., Oda, K., Misumi, Y. \& IKehara, Y. (1988). Biosynthesis of placental alkaline phosphatase and its posttranslational modification by glycophospholipid for membraneanchoring. Journal of Biological Chemistry 263, 3016-3021.

Weiss, M. J., Ray, K., Henthorn, P. S., Lamb, B., Kadesch, T. \& HARRIS, H. (1988). Structure of the human liver/bone/kidney alkaline phosphatase gene. Journal of Biological Chemistry 263 , 12002-12010.

Wyckoff, H. W., Handschmacher, M., Krishnamurthy, H. M. \& SOWADSKI, J. M. (1983). The three dimensional structure of alkaline phosphatase from E. coli. Advances in Enzymology 55, 453-480. 